\title{
The Role of Job Satisfaction in Mediating the Effect of Organizational Culture and Organizational Learning on Employee Performance at PT. Techno Motor Indonesia
}

\author{
Andreas Wahyu Gunawan ${ }^{1}$, Kansah Azzahroh ${ }^{2}$, Erny Tajib ${ }^{3}$, Deasy Aseanty ${ }^{4}$ \\ \{andreaswg@trisakti.ac.id ${ }^{1}$, kansah.azzahroh@gmail.com², ernytajib@trisakti.ac.id ${ }^{3}$ \} \\ Faculty of Economics and Business, Universitas Trisakti
}

\begin{abstract}
This study objective is to determine the role of job satisfaction in mediating the effects of organizational culture and organizational learning on employee performance at PT Techno Motor Indonesia. PT Techno Motor Indonesia is engaged in motorcycle repair, maintenance services, and spare parts sales. This study used a questionnaire as a data collection method involving 123 people. The questionnaire used a Likert scale method. This study employed proportionate stratified random sampling. Data were analyzed using SEM-PLS. The results indicated that organizational learning is having a positive but not major effect on employee's performance. Organizational culture is having a positive and major effect on employee's performance. Organizational learning had a positive and major effect on job satisfaction. Organizational culture had a positive and major effect on job satisfaction. Job satisfaction had negative and not major effect on employee's performance. Job satisfaction could not mediate the positive and significant effect of organizational culture on employee's performance. Job satisfaction could not mediate the positive and significant effect of organizational learning on employee's performance.
\end{abstract}

Keywords: Job Satisfaction; Organizational Learning; Organizational Culture; Employee Performance

\section{Introduction}

In this globalization era, companies engaged in services need to improve their service quality and innovate to get as many consumers as possible from the current market share. Organizations must make breakthroughs with innovation and technology to create a competitive advantage. Organizations that want to build a competitive advantage on the market need the best human resources [1]. Human resources (HR) are a valuable asset for the company because they contribute to its competitive advantage in increasing effectiveness and efficiency and helping to explore new business opportunities [1].

PT. Techno Motor Indonesia is one of the leading subsidiaries operating in Indonesia. Since January 2019, PT. Techno Motor Indonesia has been doing a realignment in HR management. Commitment from top management and the HR department of PT. Techno 
Motor Indonesia to continuously improve the quality of HR management. PT. Techno Motor Indonesia takes advantage of digital technology in every business activity. It has been a big challenge for PT. Techno Motor Indonesia to compete with its competitors. Employees must support the company's ability to adapt to the current situation with excellent skill and behavior following the company's strategy and goals. Therefore, at PT. Techno Motor Indonesia, it is necessary to improve employee satisfaction to increase employee productivity and performance - satisfied employees are willing to carry out duties, task and responsibilities properly.

Hendri and Fidyah et al. confirm that job satisfaction has a significant also positive impact on employee's performance. It plays an important role towards increasing employee performance - when employees are satisfied, they will do their best to complete their tasks [2], [3]. Job satisfaction applies to a person's attitude (emotional reaction) to his work-the emotional reactions can be in the form of employees feeling satisfied (positive) or feeling dissatisfied (negative) [4]. In addition, job satisfaction is considered a major component in analyzing whether the company's performance has been achieved well; it is considered one of the important indicators in directing employees to achieve organizational goals [5]. Fidyah and Setiawati found the influence between organizational culture and job satisfaction [3]. Organizational culture is the main value in an organization. These values are maintained and developed by all employees [6]. The success of employees in the organization is characterized by the ability to form behaviours suitable for the organizational culture (Stokes et al., 2019 in Tran, 2020) [5]. The culture of an organization represents its success. Fidyah et al. confirmed that organizational culture had a significant and positive effect on employee's performance [3].

Aside from organizational culture, companies also need to assess organizational learning as an attempt to manage organizational behaviour. Organizational learning has a high level of competitiveness and is considered a very appropriate strategy for organizational success in the long term [7]. Today, organizational learning is a necessity, not an option. PT. Techno Motor Indonesia strives to improve organizational learning $s$ through problem-solving training programs where employees are given exercises and case studies to learn from. It aims to develop the critical thinking of employees so and help them to pay attention to details while working. Every member of the organization must continue to innovate to face every challenge. The speed of the organization to continue to learn can be the most important source of sustainable competitive advantage for the company [8].

Thus, the basic elements needed by an organization to continue learning include patterns of information sharing, employee attitudes, learning practices, and a mindset of achieving goals [2]. Managing employee performance to make employees focused, committed, and satisfied by developing a conducive and cohesive organizational culture has always been challenging for managers and company owners.

\section{Literature Review}

Jain and Moreno describe organizational learning as the most important process for organizational growth by developing better core competencies. Organizational learning has a high level of competitiveness and is considered a very appropriate strategy for organizational success in the long term [7]. Marazi affirms that organizational learning is a very appropriate instrument to increasing employee performance, and it has a significant and positive impact towards employee performance [9]. The increase in organizational learning activities can increase knowledge, abilities, and skills to improve employee performance. However, this 
study does not align with Hendri that organizational learning has an insignificant effect on employee performance [2].

H1: Organizational learning has a significant and positives effect on employee performance.

Soomro et al. mention that an organizational culture holds the main values in the organization. These values are developed and maintained by all employees in the organisation [6]. Stokes et al. in Tran state that the success of employees in the organization is characterized by the ability to form behavior that is following the organizational culture [5].

Organizational culture is a pattern of shared perceptions adopted by organizations, which make that organization different from the others [3]. The success of the organization is seen from its practice in producing efficient and effective employee performance. Fidyah and Setiawati and Sihombing et al. confirm that organizational culture has a significant as well as positive impact on employee's performance [3], [10]. The better the organizational practice is, the better the employee performance will become. These studies, yet, contradict Harwiki, revealing that organizational culture has an insignificant as well as negative effect on employee's performance [11].

$\mathrm{H} 2$ : Organizational culture has a significant and positives effect on employee performance.

Substantially, organizational learning will affect employee satisfaction towards employee's work, so that the employee believe that the work they are currently doing is considered so important and meaningful for the progress of the organization, and employees can carry out work based on the tasks and responsibilities given [2].

Hendri confirms that organizational learning has a major and positive effect on job satisfaction [2]. More organizational learning can increase employee job satisfaction. It will happen by developing employee attitudes to make improvement of related assigned task and responsibility happen continuously and be more open minded in accepting different ideas and constructive criticism. It is in same page with the research conducted by Samreena Hamid Marazi, revealing that organizational learning is having a significant as well as positive effect on job satisfaction [9].

H3: Organizational learning has a significant and positives effect on job satisfaction.

An organizational culture certainly has the important values reflected in an organization [6]. Organizational culture is measured by the high or low level of job satisfaction of employees. Fidyah and Setiawati confirm that organizational culture positively and significantly influencing job satisfaction [3]. Excellent organizational culture can increase employee job satisfaction. This finding emphasizes that employees must practice organizational culture consistently. The study results are also supported by Soomro and Shah and Al-Sada, El-Esmael, Faisal that organizational culture positively influencing job satisfaction [6], [12]. However, these studies contradict Cronley and Kim, revealing that organizational culture has an insignificant as well as negative effect on job satisfaction [13].

H4: Organizational Culture has a significant and positives effect on job satisfaction.

Hendri writes that employees feel satisfied at work because they have support from the company-in other words, their work is appreciated and considered so important and so meaningful for the progress of the company [2]. As such, employees have integrity following the rules set by the company. Hendri confirms that job satisfaction has a positive impact on employee performance. Not only that, job satisfaction also impacted the employee performance significantly [2]. The higher employee job satisfaction level, the better the employee's performance will become. This finding is consistent with many other studies, such as Fidyah and Setiawati and Soomro et al. [3], [6]. This finding reflects the dedication of employees to support organizational success - employee satisfaction can improve performance and expand the company's business network. However, these studies contradict Adiyasa and 
Windayanti (2019) and Ndulue and Ekechukwn, revealing that job satisfaction is having an insignificant as well as negative effect on employee's performance [14], [15].

H5: Job satisfaction is having a significant and positives effect to employee's performance.

Fidyah and Setiawati examine the structural relationship between organizational culture, job satisfaction, and employee's performance [3]. Fidyah and Setiawati confirm the empirical support for indirect effect of organizational culture towards employee's performance that mediated by job satisfaction, and the indirect effect are actually bigger that the direct effect of organizational culture on employee's performance [3].

Those findings illustrate that companies with a good organizational culture allow employees to feel satisfied with their work and produce a good performance. Sopyan and Ahman confirm that organizational culture has strong attractiveness, while job satisfaction and employee performance have high attractiveness [16]. Fidyah and Setiawati confirm a bigger indirect influence (organizational culture on employee's performance thru job satisfaction) than the direct influence (organizational culture on employee's performance) [3]. However, these studies contradict Hayuningtyas, which confirms that job satisfaction cannot mediate the relationship of organizational culture to employee's performance [17].

H6: Job satisfaction mediates a significant and positives influence of organizational culture to employee's performance.

Hendri has found that organizational learning indirectly affects employee's performance thru job satisfaction [2]. It happens because organizational learning affects employee satisfaction-employees believe that their work is considered important and has a positive impact on the company, thus providing increased performance results. Marazi examined the structural relationship of the variables organizational learning, job satisfaction, and employee performance and confirmed that job satisfaction partially mediated the relation between organizational learning and employee's performance [9]. This study found empirical evidence that job satisfaction becomes mediator variable between organizational learning as well as employee's performance. Job satisfaction has a partial part as a mediator between the dependent and independent variables. It happens because when employees are involved in every learning activity, employees will feel satisfied with their work, then produce a good performance.

H7: Job satisfaction mediates the positive and significant effect of organizational learning on employee performance.

\section{Research Method}

\subsection{Research Design.}

The research tested hypotheses using a causal type of research. It employed a crosssectional approach that categorized respondents at several levels. Data were collected at the same time.

\subsection{Variable and Measurement.}

This study consisted of two independent variables (organizational learning and organizational culture), one mediating variable (job satisfaction), and one dependent variable (employee performance). Alternatives on the questionnaire used a Likert scale from 1 to 5 ( $1=$ 
Strongly Disagree (STS), 2 = Disagree (TS), 3 = Moderately Agree (CS), $4=$ Agree (S), and 5 $=$ Strongly Agree (SS)).

\subsection{Population and Sample.}

The method used was proportional stratified random sampling. The population was 177 employees (including permanent employees, contract employees, consultants, and mechanics) at PT Techno Motor Indonesia. The total samples were 123 employees.

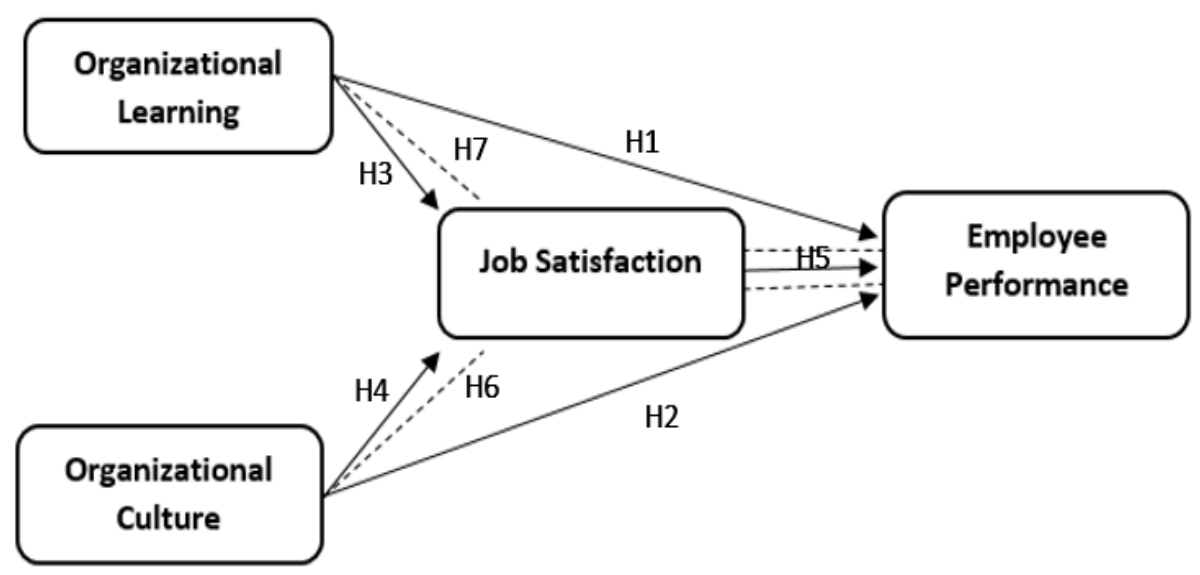

Fig. 1. Conceptual Framework

\subsection{Research Variables}

a. Job Satisfaction. Job satisfaction is measured using five dimensions: the work itself, promotional opportunities, colleagues, salaries, and supervision [18].

b. Organizational Learning. It has four dimensions: the information sharing pattern, inquiry climate, the learning practices, and the mindset of achievement [19]-[22].

c. Organizational Culture. Organizational culture has seven dimensions: courage and innovation to take risks, attention to detail, results-orientedness, human-orientedness, team-orientedness, aggressiveness, and stability [23].

d. Employee Performance. It has six dimensions: quality, quantity, timeliness, costeffectiveness, need for supervision, and interpersonal impact [24].

e. Research Instruments. The questionnaire was used extensively first, and then a trial was conducted to measure the validity and reliability of the measuring instrument. The validity test in this study was obtained from the Average Variance Extracted (AVE) value using Pooled Least Square (PLS) data analysis. Each research variable is valid if the AVE value is $>0.50$ by looking at the value of the Loading Factor $(\mathrm{LF})>0.60$. The reliability test is represented in a Cronbach's alpha that should be $>0.7$ and composite reliability of $>0.7$.

f. Data Analysis Method. Structural Equation Modeling using Partial Least Square (PLS) without the goodness of fit. 


\section{Results and Discussion}

Table 1. Hypothesis Testing Results

\begin{tabular}{|c|c|c|c|c|}
\hline Hypothesis & Description & T-statistics & Coefficient & Conclusion \\
\hline $\mathrm{H} 1$ & $\begin{array}{l}\text { Organizational learning } \\
\text { and positively affects } \\
\text { performance. }\end{array}$ & 0.431012 & 0.083574 & $\begin{array}{c}\text { Not } \\
\text { supported }\end{array}$ \\
\hline $\mathrm{H} 2$ & $\begin{array}{l}\text { Organizational culture significantly and } \\
\text { positively affects employee's } \\
\text { performance. }\end{array}$ & 2.535159 & 0.529428 & $\mathrm{H} 2$ accepted \\
\hline H3 & $\begin{array}{l}\text { Organizational learning positively and } \\
\text { significantly affects job satisfaction. }\end{array}$ & 2.955740 & 0.404152 & H3 accepted \\
\hline $\mathrm{H} 4$ & $\begin{array}{l}\text { Organizational culture positively and } \\
\text { significantly affects job satisfaction. }\end{array}$ & 2.553030 & 0.386520 & H4 accepted \\
\hline H5 & $\begin{array}{l}\text { Job satisfaction significantly and } \\
\text { positively affects employee's } \\
\text { performance. }\end{array}$ & 0.691151 & -0.130370 & $\mathrm{H} 5$ rejected \\
\hline H6 & $\begin{array}{l}\text { Job satisfaction significantly and } \\
\text { positively mediates the effect of } \\
\text { organizational culture on employee's } \\
\text { satisfaction. }\end{array}$ & -0.624013 & -0.050391 & H6 rejected \\
\hline $\mathrm{H} 7$ & $\begin{array}{l}\text { Job satisfaction significantly and } \\
\text { positively mediates the effect of } \\
\text { organizational learning on employee's } \\
\text { satisfaction. }\end{array}$ & -0.639192 & -0.052689 & H7 rejected \\
\hline
\end{tabular}

Findings indicated no significant effect of organizational learning on employee performance, but the direction of the relationship was positive between organizational learning on employee performance. Learning activities facilitate behavior change, increase efficiency and effectiveness, and facilitate the achievement of organizational goals and objectives [9]. There seemed to be a lack of employee attitudes to accept challenges, create innovation and a good working atmosphere, and cooperate. Findings indicated that organizational culture had a significant and positive effect on employee's performance. The success of an organization is seen from its pratice in producing an efficient and effective employee's performance. If the organizational culture becomes better, the employee's performance will become better.

Findings indicated that organizational learning had a significant and positive effect on job satisfaction. Organizations that prioritize learning have seen results in greater employee job satisfaction. Organizational learning at PT Techno Motor Indonesia was able to influence employee satisfaction in which employees believed that the current job was meaningful and important to them. Findings indicated that organizational culture had a significant and positive effect on job satisfaction. A very strong organizational culture will increase employee job satisfaction. These findings emphasized that organizational culture was carried out consistently by every employee.

Findings indicated that job satisfaction was having a negative as well as insignificant effect on employee's performance. Individuals can feel both positive or negative feelings depending on their perception of the work being done. This result showed a negative perception of employees towards their work, causing employee performance to decline. Findings indicated that job satisfaction could not mediate the positive and significant influence of organizational culture on employee performance. Research at PT Techno Motor Indonesia illustrated that the 
job satisfaction felt by employees was different from their expectations, so organizational culture had a stronger direct influence on employee performance than the indirect effect through job satisfaction.

Findings indicated that job satisfaction was not able mediating the positive and significant effect of organizational learning on employee performance. It was also related to the results of the $\mathrm{H} 5$ testing, which did not prove the relationship between job satisfaction and employee performance. In other words, no matter how high employee satisfaction was, it neither strengthened nor weakened employee performance. It might be driven by employee awareness their attitude towards work would have a consequence. They also seemed to realize the potential to be replaced by new and more efficient technologies and competition in the labor market.

\section{Conclusions}

Based on the findings, the following conclusions are presented. Organizational learning had a positive but did not have an significant effect to employee performances. Organizational culture had a significant and positive effect to employee performances. Organizational learning could influence job satisfaction positively and significantly. Organizational culture had a significant and positive effect to job satisfaction. Job satisfaction had a negative as well as not significant effect to employee's performances. Job satisfaction could not mediate the positive and significant effect of organizational culture to employee's performances. Job satisfaction could not mediate the positive and significant effect of organizational learning to employee's performances.

\section{Manajerial Implications}

Organizational learning is having the most dominant influence on job satisfaction. Organizational learning at PT Techno Motor Indonesia was able to influence employee satisfaction that they felt their current job was very important and meaningful. PT Techno Motor Indonesia must continue to optimize organizational learning, so that employee job satisfaction sustain. PT Techno Motor Indonesia has been doing the right strategy by prioritizing the mindset of achievement in increasing job satisfaction.

Organizational culture affected job satisfaction. Organizational culture was able to create good values as a foundation in the organization. It happened because PT Techno Motor Indonesia always encouraged employees to work together in completing work. Therefore, PT Techno Motor Indonesia must continue to create a good organizational culture to escalate employee job satisfaction. Attitudes and behavior towards work can shape job satisfaction.

Organizational culture had the most prominent influence on employee's performances. The success of an organiation is seen from its practice in producing efficient and effective employee's performances. When the organizational culture becomes better, the employee performance will also be better.

\section{References}

[1] D. M. Sikora, K. W. Thompson, Z. A. Russell, and G. R. Ferris, "Reimagining overqualified human resources to promote organizational effectiveness and competitive 
advantage," J. Organ. Eff. People Perform., vol. 3, no. 1, pp. 23-42, Jan. 2016, doi: 10.1108/JOEPP-03-2015-0012.

[2] M. I. Hendri, "The mediation effect of job satisfaction and organizational commitment on the organizational learning effect of the employee performance," Int. J. Product. Perform. Manag., vol. 68, no. 7, pp. 1208-1234, Jan. 2019, doi: 10.1108/IJPPM-052018-0174.

[3] D. N. Fidyah and T. Setiawati, "Influence of organizational culture and employee engagement on employee performance: job satisfaction as intervening variable," Rev. Integr. Bus. Econ. Res., vol. 9, no. 4, pp. 64-81, 2020.

[4] Fakhrurrazi, S. Musnadi, and T. R. I. Putra, "Determinant of job satisfaction and employee performance: a study in the house of representative (DPRK) secretariat of Pidie Jaya," Int. J. Bus. Manag. Econ. Rev., vol. 3, no. 01, pp. 249-257, 2020.

[5] Q. H. N. Tran, "Organisational culture, leadership behaviour and job satisfaction in the Vietnam context," Int. J. Organ. Anal., vol. 29, no. 1, pp. 136-154, Jan. 2021, doi: 10.1108/IJOA-10-2019-1919.

[6] B. A. Soomro and N. Shah, "Determining the impact of entrepreneurial orientation and organizational culture on job satisfaction, organizational commitment, and employee's performance," South Asian J. Bus. Stud., vol. 8, no. 3, pp. 266-282, Jan. 2019, doi: 10.1108/SAJBS-12-2018-0142.

[7] H. O. Odor, "A literature review on organisational learning and learning organisations," Int. J. Information, Bus. Manag., vol. 11, no. 3, pp. 281-295, 2019.

[8] P. M. Senge, "The art and practice of the learning organisation. The new paradigm in business: Emerging strategies for leadership and organisational change." pp. 126-138, 1990.

[9] S. H. Marazi, "The effect of organizational learning on organizational commitment, job satisfaction, and work performance among university teachers of Kashmir region.," Int. J. Enhanc. Res. Manag. Comput. Appl., vol. 6, no. 11, pp. 407-441, 2017.

[10] S. Sihombing, E. S. Astuti, M. Al Musadieq, D. Hamied, and K. Rahardjo, "The effect of servant leadership on rewards, organizational culture and its implication for employee's performance," Int. J. Law Manag., vol. 60, no. 2, pp. 505-516, Jan. 2018, doi: 10.1108/IJLMA-12-2016-0174.

[11] W. Harwiki, "The impact of servant leadership on organization culture, organizational commitment, organizational citizenship behaviour (OCB) and employee performance in women cooperatives," Procedia-Social Behav. Sci., vol. 219, pp. 283-290, 2016.

[12] M. Al-Sada, B. Al-Esmael, and M. N. Faisal, "Influence of organizational culture and leadership style on employee satisfaction, commitment and motivation in the educational sector in Qatar," EuroMed J. Bus., vol. 12, no. 2, pp. 163-188, Jan. 2017, doi: 10.1108/EMJB-02-2016-0003.

[13] C. Cronley and Y. K. Kim, "Testing the Moderated Effects of Organizational Culture, as Mediated by Job Satisfaction, within The Salvation Army Leadership \& Organization," Dev. J., vol. 38, no. 2, pp. 194-209, 2016.

[14] N. I. W. Adiyasa and W. Windayanti, "Pengaruh motivasi, kepuasan kerja, dan kepemimpinan terhadap kinerja karyawan pada PT. XYZ," J. Manaj. Strateg. dan Apl. Bisnis, vol. 2, no. 1, pp. 23-30, 2019.

[15] T. I. Ndulue and H. C. Ekechukwu, "Impact of job satisfaction on employees performance: A study of Nigerian breweries PLC Kaduna State Branch, Nigeria," Kuwait Chapter Arab. J. Bus. Manag. Rev., vol. 33, no. 3820, pp. 1-11, 2016.

[16] K. Sopyan and E. Ahman, "Pengaruh Budaya Organisasi, Kepuasan Kerja, dan 
Keterikatan Karyawan (Employee Engagement) terhadap Kinerja Karyawan di Dinas Perhubungan, Komunikasi dan Informatika (Dishubkominfo) Kabupaten Sukabumi [Effect of Organizational Culture, Employee Engagement," J. Ilmu Manaj. Dan Bisnis, vol. 6, no. 1, pp. 14-18, 2018.

[17] M. Hayuningtyas, "Peranan kepuasan karyawan dalam memediasi budaya organisasi terhadap kinerja karyawan (studi kasus pada PT JasaRaharja (Persero) Cabang Bali,” $J$. Ekon. dan Bisnis, vol. 3, no. 1, pp. 39-53, 2017.

[18] F. Luthans, Perilaku Organisasi. Yogyakarta: Andi Offeset, 2006.

[19] R. W. Pace and D. F. Faules, Komunikasi Organisasi Strategi meningkatkan kinerja perusahaan. Bandung: Remaja Rosdakarya, 1998.

[20] B. Levitt and J. G. March, "Organizational learning," Annu. Rev. Sociol., vol. 14, no. 1, pp. 319-338, 1988.

[21] R. Subramaniam, A multivariate study of the relationship between organizational learning, organizational innovation and organizational climate in the Australian hospitality industry. Australia: Swinburne University of Technology, 2005.

[22] D. A. Garvin, "Building a learning organization," Harv. Bus. Rev., vol. 71, no. 4, pp. 78-91, 1993.

[23] S. P. Robbins, Prinsip-Prinsip Perilaku Organisasi. Jakarta: Erlangga, 2002.

[24] H. J. Bernardin and J. C. A. Russel, Human Resources management: An Experimental Approach. Singapore: Mc. Graw Hill, 1993. 